\title{
METHOHEXITONE OR ETOMIDATE FOR INDUCTION OF DENTAL ANAESTHESIA
}

\author{
Harsha Boralessa and Anita Holdcroft
}

\begin{abstract}
ABSTRACI
Ninety-two patients who presented for outpatient dental extractions received methohexitone $\left(1.5 \mathrm{mg} \cdot \mathrm{kg}^{-1}, 46\right.$ patients) or etomidate $\left(0.3 \mathrm{mg} \cdot \mathrm{kg}^{-1}, 23\right.$ patients and $0.2 \mathrm{mg} \cdot \mathrm{kg}^{-1}, 23 \mathrm{pa}$ tients). The induction characteristics of both drugs such as pain on injection, involuntary muscle movements and respiratory difficulties were comparable and the theoretical disadvantages of etoridate for dental anaesthetics did not prove troublesome in practice. Muscle movements did not interfere with the dentists' manipulations and pain on injection into veins of the antecubital fossa did not occur.

The duration of operation for up to four extractions was three minutes and, following induction, anaesthesia was maintained with nitrous oxide, oxygen and halothane. Recovery was assessed by grading consciousness, airway control and motor activity. All the patients could maintain their airways one minute after the end of operation. The incidence of nausea and vorniting was significantly greater in the etomidate group.
\end{abstract}

Methohexitone is commonly used in outpatient dentistry for induction of anaesthesia. Its advantages are that it produces less cardiovascular depression than thiopentone ${ }^{1}$ and has a short half-life of 70 to 125 minutes. $^{2}$ Pain on injection and involuntary muscle movements occur in a variable percentage of unpremedicated patients, but this has not deterred anaesthetists from using this valuable drug for day case anaesthesia. Etomidate has similar advantages in terms of cardiovascular stability ${ }^{3}$ and absence of cumulation, but also is associated with no rise in plasma histamine. ${ }^{4}$ The main disadvantages of etomidate are pain on injection, ${ }^{5}$ which appears to be related to the formulation of the $\operatorname{drug}^{6}$ and may deter the use of the drug in children, and muscle movements. This latter problem may make induction of anaesthesia troublesome in the unpremedicated dental patient.

The study was undertaken to determine the feasibility of using etomidate in dental anaesthesia, and to assess its advantages and disadvantages by comparison with methohexitone during induction, anaesthesia and recovery.

\section{Methods}

\section{Patient selection}

Ninety-two consecutive patients presenting to one dental surgeon for multiple extractions were

Harsha Boralessa, M.B., B.S., F.F.A.R.C.S., Senior Registrar, Royal Postgraduate Medical School, London, England, W12 OHS. Anita Holdcroft, M.B., Ch.B., F.F.A.R.C.S., Senior Lecturer and Honorary Consultant, Department of Anaesthetics, Charing Cross Hospital, Fulham Palace Road, London, England W6 8RF. investigated and divided into two groups. Alternate patients received methohexitone, and the others etomidate. Informed consent was obtained from patients, or parents when necessary, All the patients were considered suitable for general anaesthesia and medical conditions such as epilepsy and asthma did not exclude patients from the study.

\section{Anaesthesia}

No preoperative medication or local analgesia was used. A dental prop was inserted before induction and then the intravenous injection was administered, whenever possible, into a vein in the antecubital fossa. It was given slowly over a period of thirty seconds. Forty-six patients received methohexitone in a dose of $1.5 \mathrm{mg} \cdot \mathrm{kg}^{-1}$. The remainder received etomidate 0.2 per cent in propylene glycol. In twenty-three patients etomidate $0.3 \mathrm{mg} \cdot \mathrm{kg}^{-1}$ was used, but when the results of recovery were assessed, this dose was reduced to $0.2 \mathrm{mg} \cdot \mathrm{kg}^{-1}$ in the remainder of the etomidate group. Anaesthesia was maintained with 60 per cent nitrous oxide with oxygen and halothane one per cent, delivered by continuous flow from a Walton $V$ machine through a Magill circuit with a nasal mask.

\section{OBSERVATIONS}

The time of induction of anaesthesia and its termination were noted. Patients were specifically asked if the intravenous injection was painful, and during induction and anaesthesia the occurrence of any respiratory difficulty, such as apnoea and hiccup, and muscle movements were 
TABLE 1

The Physical Characteristics and Operative Details of the Etomidate and Methohexitone Groups of Patients (Mean \pm SEM)

\begin{tabular}{|c|c|c|c|}
\hline & \multicolumn{2}{|c|}{ Etomidate } & \multirow{2}{*}{$\begin{array}{l}\text { Methohexitone } \\
1.5 \mathrm{mg} \cdot \mathrm{kg}^{-1} \\
(\mathrm{n}=46)\end{array}$} \\
\hline & $\begin{array}{c}0.3 \mathrm{mg} \cdot \mathrm{kg}^{-1} \\
(\mathrm{n}=23)\end{array}$ & $\begin{array}{c}0.2 \mathrm{mg} \cdot \mathrm{kg}^{-1} \\
(\mathrm{n}=2 \mathrm{3})\end{array}$ & \\
\hline Age (years) & $14.1 \pm 2.0$ & $13.9 \pm 1.6$ & $15.4 \pm 1.9$ \\
\hline Weight $(\mathrm{kg})$ & $41.9 \pm 3.1$ & $41.9 \pm 2.4$ & $40.2 \pm 2.4$ \\
\hline Male/Female & $11 / 12$ & $11 / 12$ & $23 / 23$ \\
\hline No. of extractions & $3.5 \pm 0.5$ & $2.8 \pm 0.3$ & $2.8 \pm 0.3$ \\
\hline Duration of (mins) & $2.7 \pm 0.4$ & $2.4 \pm 0.2$ & $2.3 \pm 0.2$ \\
\hline
\end{tabular}

recorded. Involuntary muscle movements were classified as mild when they did not interfere with anaesthesia, moderate where movement interfered with induction and maintenance of anaesthesia and severe when they resembled a convulsion. The occurrence of hypertonia in the limbs and especially in the jaw was noted.

From the time of discontinuing anaesthesia, an estimate of clinical recovery was made on a double blind basis by the nursing staff, using observations which have been described by Robertson, MacGregor and Jones. ${ }^{7}$ Three major criteria of short-term recovery were monitored and scored at one-minute intervals.

\section{Consciousness}

Patients were assumed to be fully awake when they could converse and maintain their eyes open (Score 4). Before this time, consciousness was graded as follows:

Score 0: not responding,

Score 1: responding to ear-pinching,

Score 2: eyes opening on command,

Score 3: lightly asleep with eyes opening intermittently.

\section{Ainway Control}

Airway control was assumed to be satisfactory when the patients could cough or open the mouth on command (Score 3). Until this time, airway control was graded as follows:

Score 0: airway requiring support to keep it clear,

Score 1: airway obstructed only if neck flexed,

Score 2: airway clear without support but no voluntary cough.

\section{Activity}

Three grades of activity were noted:

Score 0: none

Score 1: non-purposeful movement

Score 2: raising one arm on command.
During the time that the patients were recovering in the dental department (up to one hour following the induction of anaesthesia), the incidence of nausea and vomiting were also recorded.

Student's t-test was used to calculate the statistical significance of the recovery data and the chi-squared test as indicated.

\section{RESULTS}

\section{Selection of patients, number of extracrions and} duration of operation

The etomidate and the methohexitone groups were comparable with respect to their age, weight, and sex ratios (Table I). There was no significant difference between the means of the number of extractions $(p<0.05$ ). The duration of operation was short and averaged less than three minutes.

\section{Pain on injection}

None of the patients receiving etomidate complained of pain on injection of the drug, and two of the patients receiving methohexitone $(4 \%) \mathrm{com}-$ plained of pain on direct questioning. In these patients the veins on the dorsum of the hand had to be used for the injection site.

\section{Muscle movements}

Table II shows the incidence of muscle movements in the three groups. In only eight patients who received etomidate were no muscle movements observed and in two patients they were severe. Neither the incidence nor the severity of the muscle movements were affected by reducing the dose from $0.3 \mathrm{mg} \cdot \mathrm{kg}^{-1}$ to $0.2 \mathrm{mg} \cdot \mathrm{kg}^{-1}$. Methohexitone appeared to induce anaesthesia without these mild disturbances, but moderate and severe involuntary muscle movements occurred in nine out of 44 patients ( 20 per cent). 
TABLE II

The INCIDENCE OF INVOLUNTARY MuSCle ACTIVITY AND RESPIRATORY DIFFICULTIES IN THE METHOHEXITONE and Etomidate Groups of Patients

\begin{tabular}{|c|c|c|c|c|c|c|c|c|}
\hline \multirow[b]{2}{*}{ Anaesthetic agent } & \multicolumn{4}{|c|}{ Muscle movements } & \multirow[b]{2}{*}{ Severe } & \multirow{2}{*}{\multicolumn{2}{|c|}{$\begin{array}{cc}\text { Apnoea } \\
\text { (more } \\
\text { than } \\
\text { Hypertonia } \quad 30 s \text { ) }\end{array}$}} & \multirow[b]{2}{*}{ Hiccup } \\
\hline & $\begin{array}{c}\text { No. of } \\
\text { patients }\end{array}$ & None & Mild & Moderate & & & & \\
\hline Etomidate $0.3 \mathrm{mg} \cdot \mathrm{kg}^{-1}$ & 23 & 4 & 8 & 10 & 1 & 1 & 1 & 0 \\
\hline Etomidate $0.2 \mathrm{mg} \cdot \mathrm{kg}^{-1}$ & 23 & 4 & 9 & 9 & 1 & 1 & 3 & 0 \\
\hline Methohexitone $1.5 \mathrm{mg} \cdot \mathrm{kg}^{-1}$ & 46 & 30 & 6 & 6 & 4 & 2 & 4 & 6 \\
\hline
\end{tabular}

Jaw hypertonia occurred in five per cent in each group.

\section{Respiratory difficulties}

Four of the patients who received etomidate had apnoea of more than 30 seconds' duration, but none of these patients required ventilatory assistance. Laryngeal spasm, hiccup and cough were not observed following the administration of etomidate. Apnoea accurred in the same number of patients who received methohexitone and hiccup was a troublesome feature in six patients ( 14 per cent).

\section{Recovery}

Total recovery scores at one-minute intervals for the two groups, etomidate $0.2 \mathrm{mg} \cdot \mathrm{kg}^{-1}$ plus $0.3 \mathrm{mg} \cdot \mathrm{kg}^{-1}$ and methohexitone $1.5 \mathrm{mg} \cdot \mathrm{kg}^{-1}$ are shown in Figure 1. The individual components of these scores are shown in Figures 2, 3 and 4, with the etomidate group subdivided according to

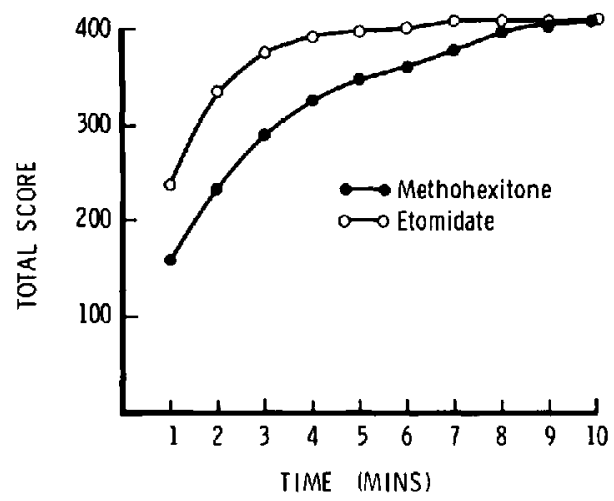

Figure 1 Total recovery scores following methohexitone/halothane/nitrous oxide or etomidate/halothane/nitrous oxide anaesthesia. Forty-six patients in each group.

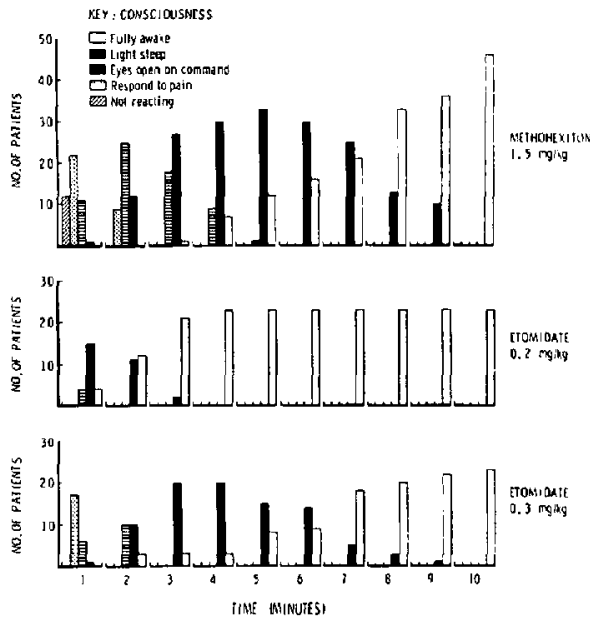

Figure 2 A comparison of methohexitone $1.5 \mathrm{mg} \cdot \mathrm{kg}^{-1}$ (46 patients) with etomidate $0.3 \mathrm{mg} \cdot \mathrm{kg}^{-1}$ (23 patients) and etomidate $0.2 \mathrm{mg} \cdot \mathrm{kg}^{-1}$ (23 patients) for induction of anaesthesia with regard to the return of consciousness.

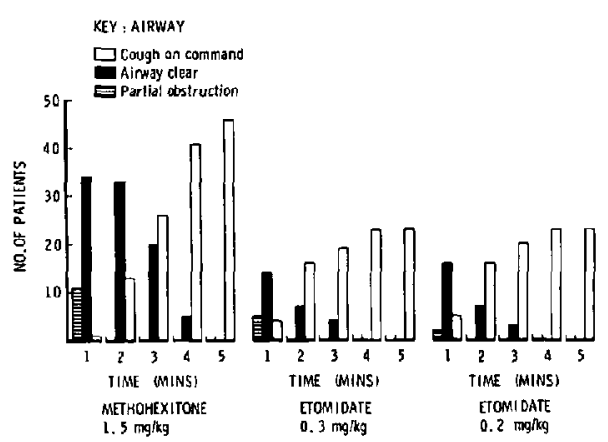

Figure 3 A comparison of methohexitone $1.5 \mathrm{mg} \cdot \mathrm{kg}^{-1}$ (46 patients) with etomidate $0.3 \mathrm{mg} \cdot \mathrm{kg}^{-1}$ (23 patients) and etomidate $0.2 \mathrm{mg} \cdot \mathrm{kg}^{-1}$ (23 patients) for induction of anaesthesia with regard to the maintenance of the airway. 


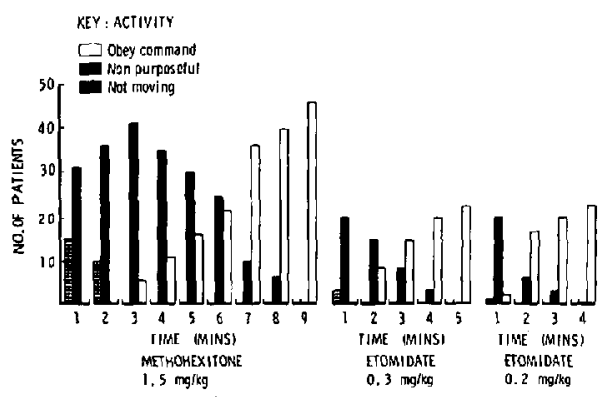

Figure 4 A comparison of methohexitone $1.5 \mathrm{mg} \cdot \mathrm{kg}^{-1}$ (46 patients) with etomidate $0.3 \mathrm{mg} \cdot \mathrm{kg}^{-1}$ (23 patients) and etomidate $0.2 \mathrm{mg} \cdot \mathrm{kg}^{-1}$ (23 patients) for induction of anaesthesia with regard to the return of co-ordinated motor activity.

\section{TABLE HI}

The Incidence of Nauses and Vomiting in the Etomidate and Methohfexttone Groups of Patients

\begin{tabular}{lccc}
\hline \hline & $\begin{array}{c}\text { Etomidate } \\
0.2 \\
\mathrm{mg} \cdot \mathrm{kg}^{-1}\end{array}$ & $\begin{array}{c}0.3 \\
\mathrm{mg} \cdot \mathrm{kg}^{-1}\end{array}$ & $\begin{array}{c}\text { Methohexitone } \\
\mathrm{mg} \cdot \mathrm{kg}^{-1}\end{array}$ \\
\hline Nausea & 2 & 10 & 0 \\
Vomiting & 0 & 7 & 2 \\
\hline
\end{tabular}

dose. Recovery of airway maintenance was similar in all groups, and clear airways were achieved in all patients one minute after finishing the operation. Return of spontaneous motor activity appeared to be delayed in those patients induced with methohexitone.

\section{Nausea and Vomiting}

The incidence of vomiting was five per cent (two out of 46 patients) in the methohexitone group and 15 per cent (seven out of 46 patients) in the etomidate groups. This is not statistically significant ( $\chi^{2}$ test). The occurrence of nausea in the etomidate group is shown in Table III and there is a highly significant difference between the etomidate and methohexitone groups ( $p<$ 0.001 ) in that the administration of etomidate increased the incidence of nausea and vomiting. After one hour of recovery no nausea or vomiting was observed in any group.

\section{Discussion}

Intravenous agents which are used in outpatient dental anaesthesia should induce anaesthesia with minimal cardiorespiratory depression, should allow adequate relaxation of the jaw and should be associated with rapid recovery and no side effects. In practice this ideal state is difficult to achieve.

Methohexitone, a methylated barbiturate, fulfils most of these criteria; but pain on injection and involuntary muscle movements such as coughing and hiccups occur in unpremedicated patients. In comparing this standard anaesthetic agent with etomidate, equipotent doses are not accurately known. Doenicke ${ }^{8}$ found that the induction characteristics of etomidate $0.3 \mathrm{mg} \cdot \mathrm{kg}^{-1}$ were similar to methohexitone $1.5 \mathrm{mg} \cdot \mathrm{kg}^{-1}$; but when $\mathrm{Kay}^{9}$ investigated the waking time after various doses of etomidate, etomidate $0.2 \mathrm{mg} \cdot \mathrm{kg}^{-1}$ was comparable with methohexitone $1.5 \mathrm{mg} \cdot \mathrm{kg}^{-1}$. The higher dose of etomidate was chosen initially because no analgesic agents were used in this study and a smooth induction was thought desirable for unpremedicated young children.

Etomidate is suitable for anaesthesia in the dental chair because it has minimal cardiovascular depressant effects and is associated with no histamine release. ${ }^{4}$ Respiratory disturbances do not occur more frequencly than with methohexitone, ${ }^{10}$ but involuntary muscle movement is common. Sedative premedication reduces the incidence of this side effect, ${ }^{5.11}$ but is unacceptable in the outpatient, particularly in the dental outpatient department, where rapid recovery is mandatory. Unpredictable muscle activity can cause concern to the anaesthetist, especially when it delays establishment of anaesthesia with the inhalational agents and the present authors were concerned that the dental prop might become dislodged. It is only the severe movements that are probably hazardous to the patient. During dental extractions in the out-patient department, it is usual for the dentist to operate almost immediately after the injection of the induction agent. This is the time when painful stimuli may increase the likelihood of muscle activity with etomidate in the absence of analgesia ${ }^{5,9}$ The surgeon in this study was not troubled by mild or moderate movements. None of the patients were aware of them postoperatively or had any lasting after-effects from them. Movements of a severity that precluded operation until inhalational anaesthesia was established occurred in two patients in the etomidate group and four patients in the methohexitone group. Hypertonus, particularly of the jaw muscles, occurred in the same number of patients in each group and presented no problem, because the dental prop inserted before induction prevented jaw closure. If this 
had become dislodged, delay in establishing adequate operating conditions would have been inevitable.

The incidence of pain on injection of methohexitone can be reduced from ten per cent to one per cent by the addition of lignocaine to the methohexitone solution, ${ }^{12}$ and by the use of a suitably large vein. ${ }^{13} \mathrm{Kay}^{14}$ was unable to reduce the pain on injection of etomidate with lignocaine added to the solution, and since then various formulations have been used to reduce the acidity and chemical irritation of the solution. The preparation of etomidate in propylene glycol was used in this study and pain on injection, which was specifically asked for, was absent. This is in contrast to some other studies, ${ }^{15.16}$ but confirms the findings of Hendry, Miller and Lees ${ }^{6}$ in relation to injecting the drug into a large vein. We found that those patients who had pain on injection did not recollect this unpleasant experience after recovering from anaesthesia. Postoperative recall of previous discomfort may make subsequent management of children for general anaesthesia difficult, but we could find no evidence that this would be the case after an etomidate induction.

Respiratory difficuities during induction of anaesthesia may be hazardous to a patient sitting in a dental chair because apnoea may lead to hypoxia if respiration is not assisted and, where the circulation may be compromised, oxygenation of vital organs may become inadequate. In this study the duration of apnoea was brief and this may have been because the time between induction of anaesthesia and surgical stimulation was very short. Hiccup interferes with the continuation of inhalational anaesthesia and was only seen in the methohexitone induction. Laryngospasm was not encountered in any of the patients.

The rate of recovery from dental anaesthesia is important to the surgeon because it will determine the number of cases which can be operated on in one session. The skill of nursing supervision may require the anaesthetist's presence until adequate reflex activity or even full consciousness has returned, and the patient also requires to return to full psychological and motor function in as short a time as possible. This study investigated short-term recovery following anaesthesia that had been induced with etomidate or methohexitone and maintained with nitrous oxide and oxygen. Breimer, ${ }^{2}$ using a sensitive gas chromatographic technique, has shown that in addition to the initial redistribution of an anaesthetic dose of methohexitone, the quick recovery of patients is the result of rapid metabolic clearance of the drug. This is confirmed by clinical studies which have been reviewed by Whitwam. ${ }^{17}$

Airway maintenance was rapidly achieved and maintained in all groups. Motor activity was delayed in the methohexitone group compared with both etomidate groups. It took twice as long for the methohexitone group of patients to make purposeful co-ordinated movements.

Early mobilisation may be responsible for the high incidence of nausea and vomiting which appears to be common after etomidate, ${ }^{14,18}$ and which this study confirms. Nausea was particularly troublesome on emergence from anaesthesia in the etomidate $0.3 \mathrm{mg} \cdot \mathrm{kg}^{-1}$ group.

This study confirms the suitability of etomidate for use as an induction agent for outpatient dental anaesthesia, except for the high incidence of nausea and vomiting on emergence from anaesthesia. The use of a small dose of etomidate and delayed ambulation may reduce this troublesome complication.

\section{ACKNOWLEDGEMENTS}

The authors thank Dr. T. McEwen and Mrs. J. Downton of the Eastman Dental Hospital for their support of this study, the staff of the operating theatre for their assistance, and the Department of Medical Illustration, Charing Cross Hospital. They are grateful to Miss Bryanna Barwick and Mrs. Pat Singh for secretarial help, and to Mr. Peter Ransom of Janssen Pharmaceuticals Lid., for kindly providing the supply of etomidate.

\section{REFERENCES}

1. Whitwam, J.G. Methohexitone. Brit. J. Anaesth. 48: $617(1976)$.

2. Breimer, D.D. Pharmacokinetics of methohexitone following intravenous infusions in humans. Brit. J. Anaesth. 48: 643 (1976).

3. Hughes, R.L. \& Mackenzie, J.E. An investigation of the centrally and peripherally mediated cardiovascular effects of etomidate in the rabbit. Brit. J. Anaesth. 50: 101 (1978).

4. Doenicke, A., Lorenz, W., Beigh, R., Bezecny, H., Uhlig, G., Kalinar, L, Praetorius, B. \& Mann, G. Histamine release after intravenous application of short-acting hypnotics. Brit. J. Anaesth. 45: 1097 (1973).

5. Holdckoft, A., Morgan, M., Whitwam, J.G. \& LUMLEY, J. Effect of dose and premedication on induction complications with elomidate. Brit. J. Anaesth. 48: 199(1976).

6. Hendry, J.G.B., Miller, B.M. \& Lees, N.W. Etomidate in a new solvent: a clinical evaluation. Anaesthesia 32: 996 (1977).

7. Robertson, G.S., MacGregon, D.M. \& Jones, 
C.J. Evaluation of doxapram for arousal from general anaesthesia in outpatients. Brit. J. Anaesth. 49: $133(1977)$.

8. Doenicke, A. Etomidate, a new intravenous hypnotic. Acta Anaesthesiologica Belgica 25: 307 (1974).

9. KAY, B. A dose-response relationship for etomidate, with some observations on cumulation. Brit. J. Anaesth. 48: 213 (1976).

10. Miller, B.M., Hendry, J.G.B. \& Lees, N.W. Etomidate and methohexitone: a comparative clinical study in outpatient anaesthesia. Andesthesia 33: 450 (1978)

11. Zacharias, M., Dundee, J.W., Clarke, R.S.J. \& Hegarty, J.E. Effect of preanaesthetic medication on etomidate. Brit. J. Anaesth. SI: 127 (1979).

12. Rowlands, D.E. Pain after methohexitone. Anaesthesia 24: 289 (1969).
13. Gorozeniuk, T., Whitwam, J.G. \& Morgan, M. Use of methohexitone, fentanyl and nitrous oxide for short surgical procedures. Anaesthesia 32: 209 (1977).

14. Kay, B. A clinical assessment of the use of etomidate in children. Brit. J. Anuesth. 48: 207 (1976).

15. Zacharias, M., Clarke, R.S.J., Dundee, J.W. \& JOHNSTON, S.B. Evaluation of three preparations of etomidate. Brit. J. Anaesth. 50: 925 (1978).

16. OJI, E.O. \& HolocrofT, A. The ocular effects of etomidate. Anaesthesia 34: 245 (1979)

17. Whitwam, J.G. The pharmacology of brietal sodium (methohexitone sodium). Anaesthesiologic und Widerbelebung 57: 1 (1972)

18. Carson, I.W., Graham, J. \& Dundee, J.W. Clinical studics of induction agents XLIII. Recovery from althesin - a comparative study with thiopentone and methohexitone. Brit. J. Anclesth. 47: 358 (1975).

\section{RÉSUMÉ}

Quatre-vingt douze patients ambulants qui se présentaient pour extractions dentaires ont reçu méthohexitone $1.5 \mathrm{mg} \cdot \mathrm{kg}^{-1}$ (46 patients) ou étomidate $0.3 \mathrm{mg} \cdot \mathrm{kg}^{-1}$ (23 patients) et $0.2 \mathrm{mg} \cdot \mathrm{kg}^{-1}$ (23 patients). Les caractéristiques des deux agents à l'induction comme lil douleur àl'injection. les mauvements involontaires et les difficultés respiratoires furent jugées comparables et le désavantage théorique de l'étomidate pour l'anesthésic dentaire n'a pas en pratique causé de problémes. Les mouvements musculaires n ont entravé en rien les manipulations dentaires et on n'a pas constaté de douleur dans la fosse an técubitale lors de l'injection.

La durée de l'intervention qui consistait à l'extraction de une à quatre dents n'a duré quc trois minutes, et après l'induction, on a maintenu l'anesthésie avec de l'oxygène-protoxyde et de l'halothane. Le réveil a été évaluế par le retour progressif à la conscience. le contrôle des voies aériennes et l'activité motrice. Tous les malades pouvaient maintenir leur voies aériennes ouvertes une minute après la fin de l'intervention. L'incidence de nausées et vomissements a été plus élevée de façon significative dans le groupe qui a reçu l'étomidate. 